\title{
Clinical outcomes of peri-implantitis treated with bone substitute and resorbable membrane: a literature review with a systematic approach
}

\author{
Desfechos clínicos do tratamento da peri-implantite com \\ substituto ósseo e membrana reabsorvível: revisão \\ da literatura com abordagem sistemática
}

\author{
Letícia Fernandes ALVES ${ }^{1}$ iD 0000-0001-8942-9898 \\ Poliana Mendes DUARTE² ID 0000-0001-8872-5943 \\ Elizabeth Ferreira MARTINEZ3 ${ }^{3}$ 0000-0002-4991-1185 \\ Marcelo Henrique NAPIMOGA ${ }^{3}$ iD 0000-0003-4472-365X \\ Marcelo SPERANDIO3 ${ }^{3}$ 0000-0003-3836-1891 \\ Julio Cesar JOLY3 iD 0000-0003-0623-7482 \\ Daiane Cristina PERUZZO3 ${ }^{3}$ 0000-0002-4745-5526
}

\section{ABSTRACT}

Objective: The objective of this review was to evaluate the outcomes of the treatment of peri-implant defects, using Guided Bone Regeneration. Methods: A literature search was performed based on the PICO methodology in the PubMed/Medline, SciELO, Lilacs electronic databases, CAPES periodicals and the Cochrane Library. We included studies using bovine mineral matrix, associated to a collagen membrane for the treatment of peri-implantitis by Guided Bone Regeneration. Results: Of 1,163 studies, 10 were included in this review after applying the evaluation criteria. A total of 269 implants were treated in 260 patients. The follow-up period ranged from 6 to 48 months. The studies evaluated outcome in terms of reduction in probing depth, gain of clinical attachment and healing of the bony defect. Due to the heterogeneity of the studies, it was not possible to perform meta-analysis. Conclusion: Treatment of peri-implant lesions with Guided Bone Regeneration is a viable modality of treatment, providing reduction in bleeding on probing, as well as gain of clinical attachment. Complete filling of the defect is, however, an unpredictable result.

Indexing terms: Bone regeneration. Dental implants. Peri-implantitis.

\section{RESUMO}

Objetivo: O objetivo desta revisão sistemática foi avaliar os desfechos do tratamento dos defeitos peri-implantares, por meio da técnica da Regeneração Óssea Guiada. Métodos: Uma pesquisa bibliográfica, baseada na metodologia PICO, foi realizada nas bases

$\sim r$

1 Faculdade Governador Ozanan Coelho. Ubá, MG, Brasil.

2 University of Florida, Departament of Periodontology. Gainsville, Florida, EUA.

3 Faculdade São Leopoldo Mandic, Instituto de Pesquisas São Leopoldo Mandic. Rua José Rocha Junqueira, 13, Swift, 13045-755, Campinas, SP, Brasil. Correspondência para / Correspondence to: DC PERUZZO. E-mail: <daiane.peruzzo@sImandic.edu.br>.

$\nabla \nabla \boldsymbol{V}$

How to cite this article

Alves LF, Duarte PM, Martinez EF, Napimoga MH, Sperandio M, Joly JC, Peruzzo DC. Clinical outcomes of peri-implantitis treated with bone substitute and resorbable membrane: a literature review with a systematic approach. RGO, Rev Gaúch Odontol. 2019;67:e20190010. http:// dx.doi.org/10.1590/1981-863720190001020190025 
de dados eletrônica PubMed/Medline, SciELO, Lilacs periódicos Capes e Cochrane Library. Foram incluídos estudos que utilizaram matriz mineral bovina, associado a uma membrana de colágeno para o tratamento da peri-implantite por Regeneração Óssea Guiada. Resultados: De 1.163 estudos, 10 foram incluídos nesta revisão, após aplicação dos critérios de avaliação. Um total de 269 implantes foram tratados em 260 pacientes. O período de acompanhamento variou de 6 a 48 meses. Os estudos avaliados reportaram redução média da profundidade de sondagem, ganho de inserção clínica e preenchimento ósseo do defeito. Devido à heterogeneidade dos estudos não foi possível realizar metanálise. Conclusão: O tratamento das lesões peri-implantares, com a técnica da Regeneração Óssea Guiada é uma modalidade viável de tratamento, proporcionando redução do sangramento à sondagem, bem como o ganho de inserção clínica. Porém, o completo preenchimento do defeito, é um resultado imprevisível.

Termos de indexação: Regeneração óssea. Implantes dentários. Peri-Implantite.

\section{INTRODUCTION}

Peri-implant diseases are defined as infectiousinflammatory lesions that develop in the tissues around the implants, and are currently considered an emerging problem [1,2]. Peri-implant diseases can be classified as peri-implant mucositis and peri-implantitis [3]. Peri-implant mucositis is defined as a reversible inflammatory reaction of the soft tissues that surround the implant in function, whereas the peri-implantitis is an inflammatory reaction associated with loss of bone support around the implant in function [4].

The primary etiological factor for the development of peri-implant diseases is the accumulation of bacterial biofilms [5]. The key parameter for the diagnosis of periimplant mucositis is the presence of bleeding on probing $[6,7]$. For the diagnosis of peri-implantitis, in addition to bleeding on probing, it is necessary to combine it with an increase in probing depth associated with bone loss around implants [6-10].

According to the 11th European Workshop on Periodontology, the prevalence of peri-implantitis and peri-implant mucositis is $22 \%$ and $43 \%$, respectively [11]. More recent studies have shown prevalence rates of periimplantitis ranging from $13.9 \%$ in a cohort study [12], $19.83 \%$ in a meta-analysis [13] to values of $20 \%$ in a crosssectional study with a follow-up period of 10 years [14].

In contrast to periodontal disease, non-surgical mechanical treatment, as an isolated treatment modality, has failed to block the progression of peri-implantitis $[15,16]$. For this reason, several surgical procedures have been tested, aiming at debriding and decontaminating the exposed surface of the implant and elimination of peri-implant defects $[17,18]$. Clinical studies suggest that together with biocompatibility of the implant surface, procedures for bone augmentation, such as guided bone regeneration (GBR) may be associated with more favorable clinical outcome [16,19-21]. Autologous bone, defined as the gold standard in bone augmentation, shows a volume loss of approximately $40 \%$ during the healing time, which will also result in greater morbidity due to the need for a second surgical site [22]. Synthetic bone substitutes, on the other hand, have shown a high stability in bone volume in the long term $[22,23]$.

In this context, a xenogeneic bovine mineral matrix substitute (Bio-Oss $®$ ) that presents physical and chemical properties similar to human bone, with osteoconductive properties, has been widely used clinically for bone augmentation in periodontal and dento-alveolar surgery in combination with implant installation [24]. This biomaterial has extensive scientific evidence for use in sinus graft surgeries [25] and alveolar preservation [26], in which volume stability and qualitative bone regeneration of the grafted areas are reported. A longitudinal study (more than 10 years) using this material of bovine origin, demonstrated volume stability, with well-reshaped lamellar bone around residual DBBM particles [27]. Studies cited in a systematic review [13] highlighted that in clinical studies on sinus graft, DBBM has been used as a positive control biomaterial.

The primary goal of the treatmentforperi-implantitisis to prevent disease progression and, at the same time, maintain the implant in function, with no signs of inflammation [28]. Several techniques have been investigated to treat defects resulting from peri-implantitis-derived sequelae, such as non-surgical and surgical treatment combined with different implant surface decontamination techniques, with or without bone filling of the peri-implant space. In a systematic review of the literature that aimed to evaluate a regenerative surgical treatment for peri-implantitis and to determine a predictable therapeutic option for clinical management, an inconsistency was demonstrated in the results reported [22]. All studies included in meta-analyzes have underlined an improvement in clinical conditions 
following regenerative surgical treatment for peri-implantitis, however, there is a lack of scientific evidence in the literature on the superiority of regenerative versus nonregenerative surgical treatment.

A second systematic review published in the same year aimed to evaluate the long-term outcome of regenerative procedures for the treatment of peri-implantitis showed that the regenerative treatment resulted in a mean filling of the bony defect of $2.41 \mathrm{~mm}$ after a minimum healing time of 36 months $[28,29]$.

In general, evidence has been reported that nonsurgical treatment does not present a favorable prognosis for cases of peri-implantitis [30], mainly due to difficult access to the implant surface $[16,31]$. Despite the lack of consensus in the literature, several studies have reported favorable results for the treatment of peri-implantitis with GBR associated with barriers for biomaterial confinement $[16,17,32,33]$. However, in view of the controversies in the literature and the lack of definition of protocols regarding the treatment for peri-implantitis, the main objective of this review was to investigate the predictability of clinical outcomes for the GBR-based approaches to treat periimplantitis, using a xenogeneic bone substitute associated with a membrane.

\section{METHODS}

This narrative review was performed following a systematic review approach based on the PRISMA methodology [34]. A bibliographic search was carried out in the electronic databases PubMed / MEDLINE, Cochrane Library, SciELO and Lilacs localizing studies published in English from January 2005 to January 2016. For this search, the PICO methodology was used [35] aiming at the establishment of the guiding question for the literature search. All search steps and reviews were appraised by two independent reviewers (LFA and DCP).

\section{PICO Methodology for Systematic Research}

The Evidence-Based Practice (EBP) proposes that the clinical problems that arise in the practice of care, teaching or research, be decomposed and then organized using the PICO strategy, which is an acronym for the words patient (P); intervention (I); comparison (C); outcomes $(\mathrm{O})$. Within the EBP these four components are the fundamental elements of the research question and the construction of the question for the bibliographical search of evidence:

- P: Refers to patient or population problem: MeSH terms: dental implant (s) OR dental implants OR peri-implantitis OR words: oral implants;

and

- Intervention: Refers to the treatment to be performed. MeSH terms: Bone Regeneration OR words of the text: guided tissue regeneration OR bone regeneration OR osteoconduction bone regeneration, bone $\mathrm{OR}$ bone grafting $\mathrm{OR}$ Bio-Oss OR collagen membrane OR Bio-Gide. regenerative surgery $O R$ regenerative treatment and

- Comparison: Refers to alternative treatment or some standard gold treatment protocol. There is no standard gold standard treatment protocol. So this question is left blank.

and

- Outcomes: Refers to the expected results. MeSH terms: Peri-implantitis OR text words: gingival bleeding on probing OR peri-implant health.

\section{The question in focus}

Will a patient diagnosed with peri-implantitis, treated with guided bone regeneration using a bovine mineral matrix (Bio-Oss ${ }^{\circledR}$, Geistlich, Wolhusen, Switzerland) associated with a collagen membrane (Bio-Gide ${ }^{\circledR}$, Geistlich, Wolhusen, Switzerland) show reduction in probing depth, disease progression and bony defect healing?

\section{Inclusion criteria}

The inclusion criteria used in this review were: randomized and non-randomized controlled clinical trials, case series, cohort studies. We included only studies that reported regenerative surgical treatment of peri-implant lesions using bone substitute (Bio-Oss ${ }^{\circledR}$ ) and resorbable membrane (Bio-Gide ${ }^{\circledast}$ ) or Bio-Oss Colagen ${ }^{\circledR}$ (Geistlich, Wolhusen, Switzerland). The studies should have a minimum of 8 implants treated and a minimum follow-up of six months. Regarding the decontamination method of implant surfaces, there were no restrictions regarding the methodology used. 


\section{Exclusion criteria}

We excluded animal studies, case reports, narrative and systematic reviews, non-clinical and clinical studies with insufficient information and studies reporting treatment of periapical peri-implant lesions.

\section{Parameters assessed}

The clinical parameters evaluated were: probing depth (PD), bleeding on probing (BOP), clinical attachment level (CAL), radiographic evidence of bony defect healing and gingival margin recession. These parameters provide vital data to establish the diagnosis of peri-implant disease Padial-Molina et al. [10] The difference in the aforementioned values before and after treatment and their weighted averages were calculated whenever the data were available in the studies.

\section{RESULTS}

\section{Characteristics of the studies}

The electronic search through the databases yielded 1,163 publications initially. Addition of subsequent terms and filters (studies published in the last 10 years and human studies only), 105 studies were obtained. From the analysis of the titles, 59 articles were excluded. The remaining 47 studies were assessed on their abstracts, of which 28 were excluded, totaling 19 articles for fullarticle assessment. An article published in January 2016 was included, totaling 20 studies analyzed in full. Of these, 10 studies fulfilled the inclusion criteria and were selected for review and 10 studies were excluded according to the established criteria, which are listed in Appendix A. Ten publications were read and included in this review, as shown in figure 1.

Regarding study design, no controlled RCT studies investigating treatment for peri-implantitis using bone and membrane substitutes compared to a control group were found. The results of this review indicated that three studies were randomized [32-36], four were retrospective $[19,33,37,39]$ and five prospective $[16,17,19,36,38]$, all of which were case series (table 1).

A total of 269 implants were treated in 260 patients aged 54 to 64 years. The follow-up period

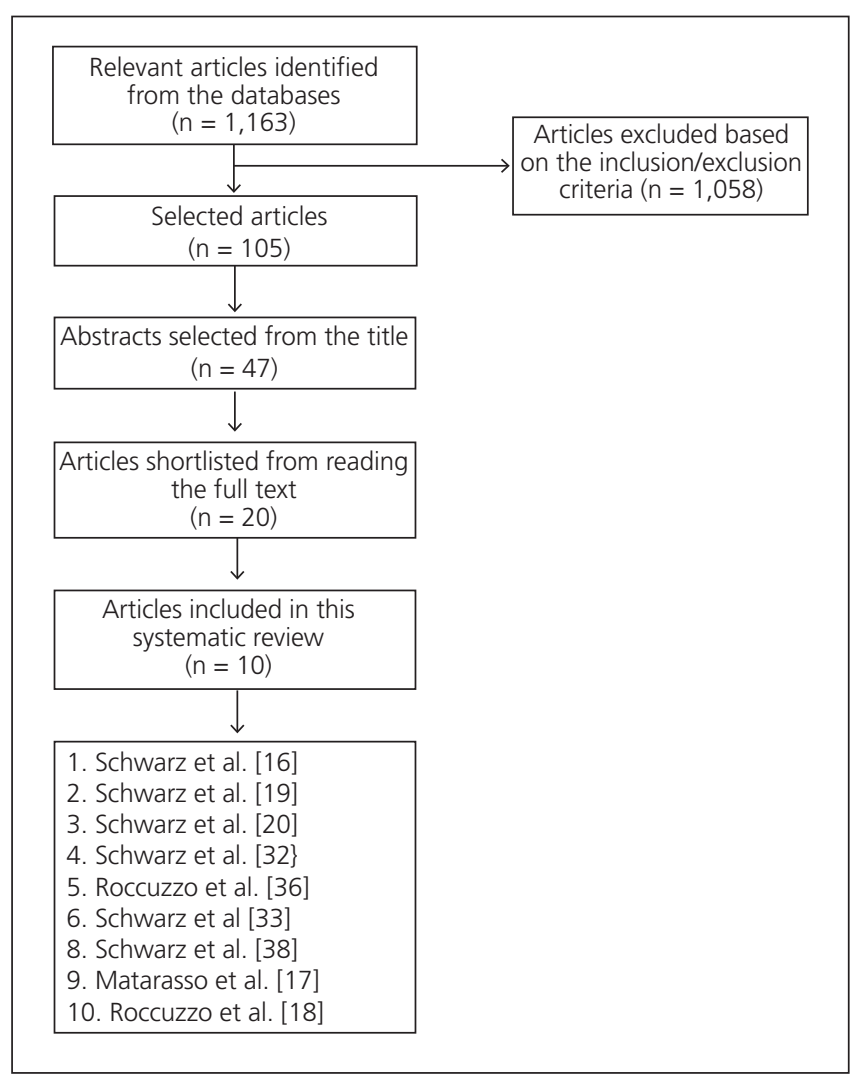

Figure 1. Flowchart of the research strategy.

ranged from $6[16,32-35,37-39]$ to 48 months $[20,36]$ (table 1).

According to the characteristics of the sample, three studies $[16,19,20]$ (33.3\%) reported that the treatment was performed on nonsmoking patients; five studies $(55.5 \%)$ included smoking patients and two studies $[33,37](11.1 \%)$ did not provide information regarding the characteristics of the sample studied (table 1).

Regarding the material used, three sequential studies compared the use of the Bovine Mineral Matrix (BioOss ${ }^{\circledR}$ ) associated with a collagen membrane (Bio-Gide ${ }^{\circledR}$ ) to the hydroxyapatite graft $\left(\right.$ Ostim $\left.^{\circledR}\right)[16,19,20]$. Some studies have reported the technique using Bio-Oss ${ }^{\circledast}$ associated with the Bio-Gide ${ }^{\circledR}$ membrane $[17,32,33,37,38]$ or the biomaterial Bio-Oss associated with collagen 10 (Bio-Oss Collagen $\left.{ }^{\circledR}\right)[18,36]$. Regarding the type of implant, a great diversity was found in relation to size, surface treatment and trademarks (table 2).

Prior to surgery, baseline periodontal treatment consisted of mechanical removal of bacterial biofilm and calculus as well as oral hygiene instruction in all studies. One study (10\%) used laser (Er-YAG) in a single session to 
Table 1. Characteristics of the selected studies. Legend: CS: case series; M: male; F: female; GT: Group test; NHA: nanocrystalline hydroxyapatite; GC: Group control; NA: not available.

\begin{tabular}{|c|c|c|c|c|c|}
\hline Reference & Study design & Patients (n) & Implants (n) & Smoking status & Follow-up (months) \\
\hline 1 Schwarz et al. [16] & Case series / prospective. & $M=8 ; F=22$ & $\begin{array}{c}\text { GT: } n=11 \\
(\mathrm{NHA}) \\
\text { GC: } \mathrm{n}=11 \\
\text { (Bio-Oss + Bio-Gide) }\end{array}$ & non-smokers & 6 \\
\hline 3 Schwarz et al. [20] & Case series / retrospective & 19 & $\begin{aligned} G T: n & =9 \\
G C: & =10\end{aligned}$ & Non-smokers & 48 \\
\hline 4 Schwarz et al. [32] & $\begin{array}{l}\text { Randomized controlled } \\
\text { case study }\end{array}$ & $\begin{array}{c}32 \\
M=11 ; F=21\end{array}$ & 38 & Light smokers & 6 \\
\hline 7 Schwarz et al. [37] & $\begin{array}{c}\text { Randomized } \\
\text { controlled / retrospective }\end{array}$ & $\begin{array}{c}21 \\
M=6 ; F=15\end{array}$ & 21 & NA & 48 \\
\hline 8 Schwarz et al. [38] & CS - Prospective & $\begin{array}{c}10 \\
M=5 ; F=5\end{array}$ & 13 & $\begin{array}{l}\text { Não-fumante/fumante } \\
<10 \text { cigarettes/day }\end{array}$ & 6 \\
\hline 9 Matarasso et al. [17] & CS - Prospective & $\begin{array}{c}11 \\
M=5 ; F=6\end{array}$ & 11 & 5 smokers & 12 \\
\hline 10 Roccuzzo et al. [18] & Prospective & 75 & 75 & 11 smokers & 12 \\
\hline
\end{tabular}

reduce the signs of inflammation [39], six studies (60\%) used plastic curettes combined with $0.2 \%$ chlorhexidine solution supra-gingivally and $0.2 \%$ chlorhexidine gel subgengivally $[16,19,20,32,33,37]$. Three studies (30\%) reported non-surgical treatment with supra and subgingival debridement, but did not expand on how this treatment was performed $[17,18,36]$ (table 3).

Treatment strategies varied between studies in terms of antibiotics prescription, i.e., pre and/or postsurgically. Five studies (50\%) did not provide data on whether any medication was prescribed $[16,19,20,32,33]$ and one study (10\%) reported prescription medication, but did not specify the drug prescribed [37]. Three studies (30\%) used a combination of amoxicillin and clavulanic acid $[17,18,36]$ and one study (10\%) used penicillin or clindamycin [38] (table 3).

After the initial phase, surgical access was performed. All studies performed mechanical decontamination of the implant surface. A study (10\%) used a curette and a titanium brush [18] and one study (10\%) used a stainless steel curette [17]. The study by Schwarz et al. [38] reported using mechanical treatment with curettes, which were not specified. Five studies (50\%) performed surface smoothening of the implant, i.e., implantoplasty, with the aid of rotatory instruments $[17,32,33,37,38]$ (table 4).

The disinfection protocol during surgical access for chemical decontamination of the implant surface varied significantly. Five studies (50\%) used sterile saline $[16,17,19,20,38]$, two studies (20\%) $[18,36]$ used $24 \%$ EDTA for 2 minutes combined with $1 \%$ chlorhexidine gel for 2 minutes. Three studies (numbers 4, 6 and 7) (30\%) compared saline solution with Er-YAG laser (infrared, 2,940 nm) to decontaminate the implant surface $[32,33,37]$, but failed to demonstrate the superiority of a decontamination method (table 4).

\section{Surgical treatment}

Regarding the type of access, a full surgical flap was used in all studies. 
Table 2. Description of the methodology employed in each study. Legend: NHA: nanocrystalline hydroxyapatite; GT: group test; TPS: titanium plasma spray; GC: grupo control; SLA: (sandblasted large-grit acid etching).

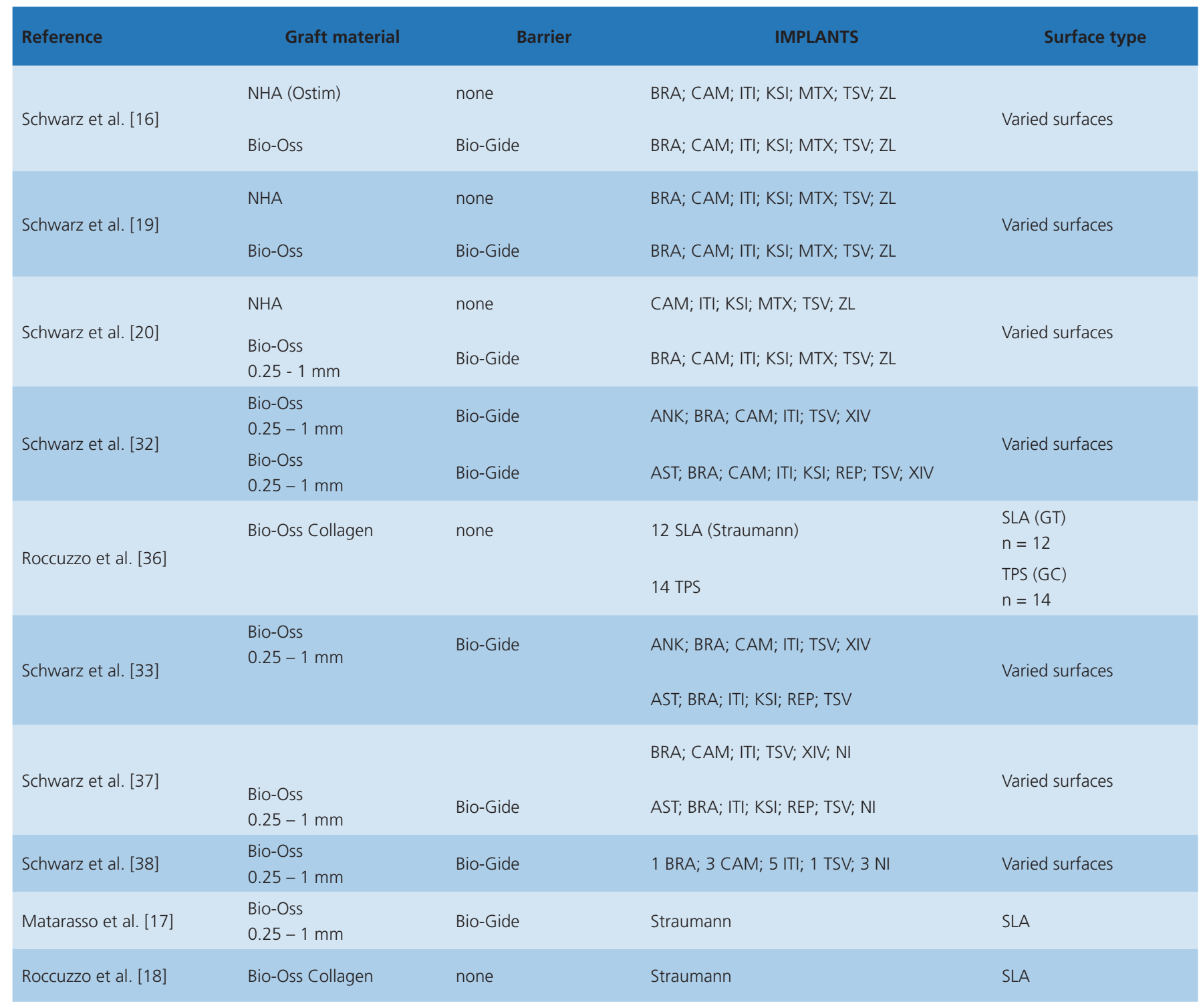

Bovine Mineral Matrix $\left(\right.$ Bio-Oss $\left.^{\circledR}\right)$ combined with a collagen membrane (Bio-Gide $\AA$ ) was used in 8 studies $[16,17,19,20,32,33,38]$ while two studies used a $10 \%$ collagen bovine mineral matrix (Bio-Oss Collagen $®$ ) $[18,36]$.

\section{Clinical parameters}

i) Bleeding on probing

The ten studies included evaluated bleeding on probing at baseline and post-operatively.

There was a reduction in bleeding on probing in all studies. The percentage of reduction varied from $13.6 \%$ [17] to $85.20 \%$ [36] (table 1) ii) Probing depth

Of the ten studies included, all provided information on the baseline and post-operative probing depths. There was a reduction in probing depth in all studies. Such reduction varied from an average of $1.1 \mathrm{~mm}[20,33]$ to $4.1 \mathrm{~mm}$ [17]. This average was regular in all studies, except in the study by Matarasso et al. [17], which reported a reduction in probing depth of $4.1 \mathrm{~mm}$, higher than those found in other studies (table 5).

iii) Bony defect healing

Of the ten studies included, only two (20\%) reported information on bone healing of the 
Table 3. Pre-treatment protocol described for each study.

\begin{tabular}{|c|c|c|c|c|}
\hline Reference & Patient age (years) & Calibration & Pre-treatment & Antibiotics \\
\hline 1 Schwarz et al. [16] & $54.4 \pm 12.5$ & Yes & Deb. Plastic curettes; $0.2 \%$ CLX gel sub. / sol. supra & NA \\
\hline 2 Schwarz et al. [19] & $54.4 \pm 12.5$ & Yes & Deb. Plastic curettes; $0.2 \%$ CLX gel sub. / sol. supra & NA \\
\hline 3 Schwarz et al. [20] & $54.4 \pm 12.5$ & Yes & Deb. Plastic curettes; $0.2 \%$ CLX gel sub. / sol. supra & NA \\
\hline 4 Schwarz et al. [32] & $60.8 \pm 10.9$ & Yes & OHI; debridement & NA \\
\hline 5 Roccuzzo et al. [36] & $60 \pm 7.9$ & Yes & $\begin{array}{l}\text { OHI, Deb and } \\
\text { Prophylaxis IPeSS }<20 \%\end{array}$ & Amox. + clavul. \\
\hline 6 Schwarz et al. [33] & $62.3 \pm 10.0$ & Yes & Non-surgical treatment & NA \\
\hline 7 Schwarz et al. [37] & $62.2 \pm 0.0$ & Yes & OHI; debridement & NA \\
\hline 8 Schwarz et al. [38] & $58.8 \pm 16.6$ & Yes & laser Er-YAG & Penicilin ou clindamicina \\
\hline 9 Matarasso et al. [17] & $63.6 \pm 8.9$ & NA & OHI; debridement (supra and sub) & Amox. + clavul. \\
\hline 10 Roccuzzo et al. [18] & $57.8 \pm 8.5$ & Yes & OHI; Deb; IPeSS < 20\% & Amoxicilina + ácido clavul. \\
\hline
\end{tabular}

Legend: NA: not available; Deb: debridement; $0.2 \%$ CLX gel sub.: chlorhexidine gel subgingivally; sol. supra: solution supragingivally; OHI: oral hygiene instruction; Amox. + clavul.: amoxicillin + clavulanic acid.

Table 4. Intraoperative debridement and decontamination methods used in each study.

\begin{tabular}{|c|c|c|}
\hline References & Implantoplasty & $\begin{array}{l}\text { Surgical intervention } \\
\text { Decontamination method }\end{array}$ \\
\hline Schwarz et al. [16] & - & $\begin{array}{l}\text { Plastic curette + saline } \\
\text { Plastic curette + saline }\end{array}$ \\
\hline Schwarz et al. [19] & - & $\begin{array}{l}\text { Plastic curette + saline } \\
\text { Plastic curette + saline }\end{array}$ \\
\hline Schwarz et al. [20] & - & $\begin{array}{l}\text { Plastic curette + saline } \\
\text { Plastic curette + saline }\end{array}$ \\
\hline Schwarz et al. [32] & + & $\begin{array}{l}\text { Plastic curette + saline } \\
\text { Er-YAG }\end{array}$ \\
\hline Roccuzzo et al. [36] & - & $\begin{array}{l}24 \% \text { EDTA }+1 \% C L X \\
\text { Plastic curette }\end{array}$ \\
\hline Schwarz et al. [33] & + & Plastic curette / Er-YAG \\
\hline Schwarz et al. [37] & + & Plastic curette / Er-YAG \\
\hline Schwarz et al. [38] & + & Curettes + saline \\
\hline Matarasso et al. [17] & + & Saline \\
\hline Roccuzzo et al. [18] & - & $\begin{array}{l}24 \% \text { EDTA }(2 \mathrm{~min})+1 \% \operatorname{CLX}(1 \mathrm{~min}) \\
\text { Curette and titanium brush }\end{array}$ \\
\hline
\end{tabular}

Legend: Er-YAG (laser); CLX: chlorhexidine; EDTA: (Ethylenediamine tetraacetic acid). 
Table 5. Description of the outcomes for each of the shortlisted studies.

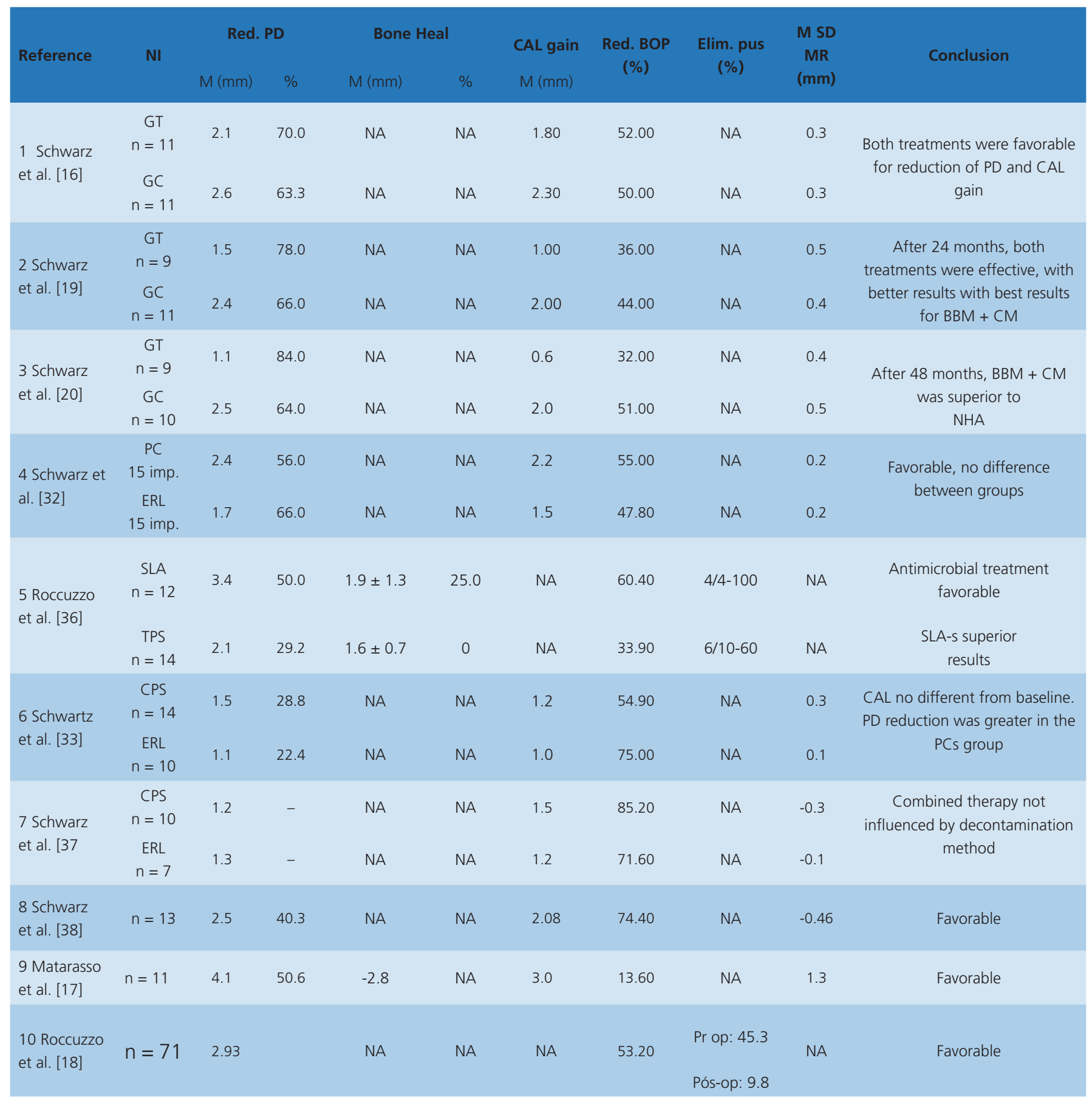

Legend: NI: number of implants; GT: Group test; GC: Group control; PC: plastic curettes + saline; ERL: Er-YAG Laser; SLA: sandblasted large grit acid etching; TPS: titanium plasma spray; imp.: implants; Red. PD: Reduction in probing depth; NA: not available; CAL: clinical attachment level; Red. BOP: reduction in bleeding on probing; Elim. pus: elimination of pus; M DP RM: Mean of standard deviations from mucosal reduction; Pre-op: Pre-operatively; Post-op.: Post-operatively; BBM: bovine bone matrix; CM: collagen membrane; NHA: nanocrystalline hydroxyapatite; SLA-s: SLA-treated surface.

defect $[17,39]$. In the study by Roccuzzo et al. [36], bony defect healing was on average $1.9 \pm$ $1.3 \mathrm{~mm}$ in the test group (group that evaluated SLA surface implants) and $1.60 \pm 0.7 \mathrm{~mm}$ in the control group (group that evaluated implants of TPS surface). The reductions were statistically significant in each group, but without differences between groups. Complete filling of the defect 
was observed in 3 of the 12 treated cases of the test group (25\%), whereas in the control group there was no complete filling of the defect in any of the cases. In the study by Matarasso et al. [17], the final bony defect healing was measured from the implant shoulder to the deepest aspect of the defect and averaged $2.8 \mathrm{~mm}$. Infrabony healing, measured from the deepest aspect of the defect to the mesial or distal bony crest, was on average 3 $\mathrm{mm}$, with a healing percentage of $93.3 \pm 13.0 \%$, on average (table 1).

Four studies reported only a reduction in translucency around the peri-implant defect $[16,19,20,32]$. While other four studies did not report any bone gain $[18,33,37,38]$.

iv) Clinical attachment level

Regarding clinical attachment levels, two studies did not report data on this variable $[18,39]$. For all other studies, there was CAL gain in $100 \%$ of the cases. This gain varied from 0.6 [37] to $3.0 \mathrm{~mm}$ [17] on average. In particular, sequential studies by Schwarz et al. [16] showed a reduction in CAL in the two groups evaluated (GT: NHA, GC: Bio-Oss ${ }^{\circledR}$ + Bio-Gide $\left.{ }^{\circledR}\right)$, though the gains were higher in the 6 -month follow-up [16]. The authors suggest that this result may be related to the increase in plaque index, observed along the follow-up time. Similar results were obtained in sequential studies by Schwarz et al. [32,33], where the gains obtained after 6 months were not maintained in the followup of 24 months (table 1).

v) Gingival margin recession

Only two studies did not report data on gingival margin recession $[18,36]$. The results point to an increase in gingival margin recession in all studies $(100 \%)$. The studies by Schwarz et al. [33,37] showed lower mean gingival margin recession, which was $0.1 \mathrm{~mm}$, whereas Schwarz et al. [20] demonstrated the highest mean, namely $0.5 \mathrm{~mm}$. In order to minimize gingival margin recession, a study proposed the use of the subepithelial connective tissue graft concomitant to the regenerative surgical procedure [38]. After a period of six months, the authors reported an overall increase in gingival recession $(0.59 \pm 0.54 / 0.98 \pm$ 0.81). However, on the buccal aspect, no increase in recession was reported and, in two implants, a mild coronal migration of the gingival tissue was noted $(0.79 \pm 0.84 / 0.76 \pm 0.38)$ (table 1$)$.

\section{DISCUSSION}

The lack of well-defined protocols to manage periimplantitis warrants a systematic review, which was the original objective of this study. The authors did, however, face important challenges in performing this particular study, namely the lack of RCTs and also undefined gold-standard approaches against which to establish comparisons. Evidence quality assessments, including study limitations, inconsistency of results, indirectness of evidence, imprecision and reporting bias, should be discussed together with effect size obtained from synthesis such as meta-analysis. In systematic reviews on treatment of peri-implantitis, quality assessments are often performed as a simple format evaluation and scarcely presented and discussed with impact [40].

The limitations encountered and raised by the authors have therefore rendered this review unable to reach the status of a systematic review. We therefore performed a narrative literature review following a systematic approach in order to report on the interesting findings encountered throughout this endeavor.

There is evidence that non-surgical therapy is ineffective in advanced cases of peri-implantitis [30] because access to the surface of the contaminated implant is limited $[16,31]$. By contrast, surgical therapy for the treatment of peri-implant lesions facilitates removal of granulation tissue from the defect area and decontamination of the exposed implant surface [18,32]. These data are supported by results from previous experimental studies suggesting that combining regenerative approaches may be associated with better histological findings $[15,41]$. From the clinical point of view, this beneficial effect seems to be potentially influenced by the physicochemical properties of the bone substitutes or defect configuration [20].

Analysis of the studies revealed common traits in treatment approaches, including a non-surgical pretreatment phase, surgical therapy phase to target the cause and a phase of maintenance care. The surgical approach consisting of raising a mucoperiosteal flap was performed where a deep peri-implant pocket $(>=5 \mathrm{~mm}$ ) was detected to facilitate access to the contaminated implant surface. 
In this review, studies investigating a single material (Bio-Oss ${ }^{\circledR}$ or Bio-Gide ${ }^{\circledR}$ ) were excluded to prevent weakening of the comparisons. An exception was made to two studies $[18,39]$ that used only Bio-Oss Collagen ${ }^{\circledR}$. These studies were included, because this material is sufficiently dense to allow stabilization without the need for barriers $[42,43]$. The use of the barrier membrane to cover the grafted area is often an operator-dependent decision. Barrier membranes are intended to stabilize the graft and prevent epithelial growth in the grafted area, thus favoring the progression of bone cell population into the bony defect [22]. Sahrmann et al. [44] demonstrated that GBR using the bone substitute and membrane represents the bulk of the published literature on regenerative surgical treatment for peri-implantitis. Differently from the present study, Sahrmann's work included several types of bone substitutes combined with either resorbable or non-resorbable membranes, with most studies being case reports with missing clinical data, which rendered metaanalysis unfeasible. Roos-Jansaker et al. [45,46], Figuero et al. [47] and Chan et al. [48], however, reported that the use of a barrier membrane was expensive, time-consuming and technique-sensitive, the latter associated to a high risk of material exposure and no evidence of superior clinical outcomes in terms of PD and BOP reduction.

A 6-month follow-up case series by Schwarz et al. [16] concluded that the application of alloplastic material (nanocrystalline hydroxyapatite -Ostin ${ }^{\circledR}$ ) and bovine xenograft (Bio Oss $\left.{ }^{\circledR}\right)$, covered with a collagen membrane (Bio Gide ${ }^{\circledR}$ ) resulted in significant improvement in clinical parameters (PD and $\mathrm{CAL}$ ) in the healing period. A 2-year follow-up of the same case-series published by Schwarz et al. [19] also reported successful bone regeneration of the peri-implant defect. Both provided a significant reduction in PD and gain in CAL. In the 4-year follow-up [19], however, the group receiving the combination of bovine xenograft and collagen membrane was clinically superior compared to the isolated nanocrystalline hydroxyapatite. This difference can be influenced by the physicochemical properties of the bone graft replacement applied in the long term. For Daugela et al. [22], regarding the aforementioned studies, different biomaterials were used, so comparisons should be interpreted with caution.

Some of the surgical protocols included administration of preoperative and/or postoperative systemic antibiotics $[17,18,36,38]$ and $100 \%$ of the studies used chlorhexidine mouthwash postoperatively. An RCT demonstrated that the use of systemic antibiotics had no impact on treatment outcome of smooth surface implants, although a positive effect was observed in the treatment of implants with a modified surface [49]. In the present study, no RCT was found comparing treatment with or without systemic antimicrobial agents and it was not possible to assess the impact of antimicrobial therapy on treatment.

As inclusion criterion, all ten studies of this review evaluated implants with PD $\geq 5 \mathrm{~mm}$ and BOP positive, as recommended by Aghazadeh et al. [50] and Froum et al. [51]. It should be noted, however, that all studies included basic periodontal treatment consisting of mechanical biofilm control and $0.2 \%$ chlorhexidine mouthwash prior to surgical treatment. Therefore, the PD and BOP values described at the beginning of the study may be different from those found before the surgical intervention, as they included a non-surgical treatment phase. Implants with peri-implant disease and PD $\geq 8 \mathrm{~mm}$, or with $50 \%$ or greater loss of implant length have no indication for conservative treatment, and thus should be removed [10,52].

$\mathrm{BOP}$ reduction is an important parameter for evaluating the effectiveness of the treatment protocol for peri-implant diseases [31]. No studies have reported complete absence of BOP after treatment, though BOP reduction ranged from $13.6 \%$ [17] and $85.20 \%$ [36], on average. Comparing against other studies, Matarasso et al. [17] reported the lowest mean at the end of treatment $(6.1 \pm 24 \%)$, but also reported the lowest mean prior to treatment $(19.7 \pm 40.1 \%)$, as the baseline values of such studies were not recorded at the time of diagnosis, but 8-10 weeks after the initial therapy, which consisted of sub and supragingival mechanical debridement.

PD reduction was reported in $100 \%$ of the studies evaluated, with the study by Matarasso et al. [17] recording the highest mean reduction after 12 months of follow-up (from $8.1 \pm 1.8$ to $4.0 \pm 1.3 \mathrm{~mm}$ ). By contrast, the study by Schwarz et al. [20] presented the lowest mean (from $6.9 \pm 0.6$ to $5.8 \pm 0.7 \mathrm{~mm}$ ) after a period of 24 months. Although both had used GBR, different decontamination methods were reported. The study by Schwarz et al. [20] reported the use of plastic curettes and saline solution, while Matarasso et al. [17] used implantoplasty combined with jets of glycine-based powder. Regarding surface decontamination method, the literature is inconclusive in terms of the most suitable approach $[10,47,52]$. This corroborates the findings from the present review, in which several methods of decontamination were used during 
surgical access. In addition, Heitz-Mayfield \& Mombelli [31] reported that a reduction in bacterial load and suppression of pathogens in the peri-implant pocket may be sufficient to establish a balance between peri-implant microbiota and host response, though they question whether the implant surface may be biocompatible for a new direct bone/implant contact, i.e., for new osseointegration.

Regarding CAL, two studies did not report this variable $[18,36]$. For the remaining studies, there was gain of attachment in $100 \%$ of the cases. This gain varied from 0.6 [20] to $3.0 \mathrm{~mm}$ [17] on average. In particular, sequential studies by Schwarz et al. [16] demonstrated CAL reduction in the two groups evaluated (GT: NHA, GC: Bio-Oss $®+$ Bio-Gide $\AA)$, but the gains were highest at the 6-month follow-up [16]. The authors suggested that such findings may be related to an increase in the plaque index, which was observed along the follow-up time thereafter.

Although peri-implantitis is on the rise, some aspects regarding the treatment of peri-implant disease remain unresolved, such as the influence of the implant surface and its topography treatment outcome. The study by John et al. [53] indicated that surface roughness does not seem to be the only factor influencing the amount and speed of biofilm formation. The studies included in this review reported on several implant brands, designs and surfaces $[16,19,20,32,33,37,39]$. Differences in outcomes have been reported, however, for implants with TPS or SLA surfaces, in which the SLA surface showed superior results in relation to TPS [36]. Similar results were reported in the studies of Heitz-Mayfield [31] and Papathanasiou et al. [54]. By contrast, the study by John et al. [52] indicated that surface roughness does not appear to be the only factor influencing the amount and rate of biofilm formation. In addition, Dalago et al. [55] attempted to establish the potential risk factors for peri-implantitis and concluded that the surface features of the implants were not related to the prevalence of this disease.

In the literature search for this review, no RCTs were found comparing the outcome peri-implantitis treatment using GBR and bone substitute combined with a collagen membrane to an adequate control group. This may be due to the lack of protocols, or because a gold standard approach for the treatment of peri-implantitis has not yet been established. Consequently, studies providing a lower level of evidence, such as case series and RCTs with a different objective, such decontamination methods, have been included in the benefit of extracting relevant clinical data reported therein. In addition, the number of cases included in most studies was relatively low (10 to 75) and the follow-up period short, ranging from 6 months to 4 years, and the intervals between visits varied greatly [weekly in the first 2 months and monthly thereafter $[5,16,19,20,32,33,38]$; weekly in the first 6 weeks and once every 3 to 6 months thereafter [17], with 2 studies not reporting their recall times $[18,39]$. Therefore, these results should be interpreted with caution, since, for clinical decision-making, the ideal scenario should be studies including larger sample sizes and longer follow-up.

Consequently, it was not possible to establish strict outcome comparisons for all studies based on follow-up times. Furthermore, short observation periods strongly limit the clinical relevance of a given treatment. It is important to note that in the present review, favorable outcomes have been observed in the selected studies, although disease progression or recurrence as well as implant loss have also been reported.

Due to significant heterogeneity between the selected studies in terms of their design, decontamination methods of the implant surface and the presence of morphologically different peri-implant lesions, their extension and severity, meta-analysis was possible to perform. Future well-designed RCTs with longer follow-up periods are still needed to fully explore the effectiveness and long-term prognosis of treatment for peri-implantitis using GBR as well as the cut-off point between conservative treatment and and implant removal.

The number of patients with peri-implantitis will increase in the near future. Establishing a standard treatment protocol for peri-implantitis is an urgent task for the specialists' community. Clinical trials directed to this specific condition has proven extremely challenging for researchers, as dental implants are a high-cost medical option in many countries, and peri-implantitis may be classified as an asymptomatic iatrogenic disease [40]. In the meantime, the clear lack of well-defined protocols and gold-standard approaches to tackle peri-implantitis reiterate the importance of meticulous preventative strategies in an attempt to arrest or delay the onset of the disease [56].

In conclusion, peri-implant defects treated with GBR using bovine mineral matrix associated with a collagen membrane resulted in favorable short-term outcomes in terms of probing depth and gain of clinical attachment, although complete filling of the bony defect was not a predictable outcome. 
Given the heterogeneity of the methodology described in the selected studies, meta-analysis proved unfeasible.

Studies involving well-designed randomized controlled clinical trials that investigate the impact of defect configuration, different grafting materials, implant surface decontamination methods and follow-up greater than one year are needed to prove the effectiveness of the method.

\section{Collaborators}

LF ALVES: study design, data collection, manuscript drafting. PM DUARTE: manuscript drafting, edition and review. EF MARTINEZ: study design, manuscript draft and review. MH NAPIMOGA: data collection and analysis. M SPERANDIO: data analysis, manuscript drafting and final edition. JC JOLY: study design and final review. DC PERUZZO: study design, data collection, data analyses and manuscript drafting.

\section{REFERENCES}

1. Tonetti MS, Chapple ILC, Jepsen S, Sanz M. Primary and secondary prevention of periodontal and peri-implant diseases: Introduction to, and objectives of the 11th European Workshop on Periodontology consensus conference. J Clin Periodontol. 2015;42 Suppl 16:S1-4. http://dx.doi.org/10.11 $11 /$ jcpe. 12382

2. Henriques PSG, Rodrigues AEA, Peruzzo DC, Okajima LS, Trevensolli N. Prevalence of peri-implant mucositis. RGO, Rev Gaúch Odontol. 2016;64(3):307-11. http://dx.doi.org/10.15 90/1981-8637201600030000103009

3. Zitzmann NU, Berglundh T. Definition and prevalence of periimplant diseases. J Clin Periodontol. 2008;35(8 Suppl):286-91. http://dx.doi.org/10.1111/j.1600-051X.2008.01274.x

4. Berglundh T, Armitage G, Araujo MG, Avila-Ortiz G, Blanco J, Camargo PM, et al. Peri-implant diseases and conditions: Consensus report of workgroup 4 of the 2017 World Workshop on the Classification of Periodontal and PeriImplant Diseases and Conditions. J Clin Periodontol. 2018;45 Suppl 20:S286-S291. http://dx.doi.org/10.1111/jcpe.12957

5. Schwarz F, Schmucker A, Becker J. Efficacy of alternative or adjunctive measures to conventional treatment of periimplant mucositis and peri-implantitis: a systematic review and meta-analysis. Int J Implant Dent. 2015;1(1):22. http:// dx.doi.org/10.1186/s40729-015-0023-1

6. Armitage GC, Xenoudi P. Post-treatment supportive care for the natural dentition and dental implants. Periodontol 2000. 2016;71(1):164-184. http://dx.doi.org/10.1111/prd.12122

7. Jepsen S, Berglundh T, Genco R, Aass AM, Demirel K, Derks $J$, et al. Primary prevention of peri-implantitis: Managing peri-implant mucositis. J Clin Periodontol. 2015;42 Suppl 16:S152-7. http://dx.doi.org/10.1111/jcpe.12369

8. Hämmerle C, Glauser R. Clinical evaluation of dental implant treatment. Periodontol 2000. 2004;34:230-239.

9. Lang NP, Berglundh T. Periimplant diseases: where are we now?--Consensus of the Seventh European Workshop on Periodontology. J Clin Periodontol. 2011 Mar;38 Suppl 11:17881. http://dx.doi.org/10.1111/j.1600-051X.2010.01674.x

10. Padial-Molina M, Suarez F, Rios H, Galindo-Moreno P, Wang $\mathrm{HL}$. Guidelines for the Diagnosis and treatment of peri-implant diseases. Int J Periodontics Restorative Dent. 2014;34(6):e102-1 1. http://dx.doi.org/10.11607/prd. 1994.

11. Derks J, Tomasi C. Peri-implant health and disease. A systematic review of current epidemiology. J Clin Periodontol. 2015;42 Suppl 16:S158-71. http://dx.doi.org/10.1111/ jсpe. 12334

12. Nobre MA, Maló P. Prevalence of periodontitis, dental caries, and peri-implant pathology and their relation with systemic status and smoking habits: Results of an opencohort study with 22009 patients in a private rehabilitation center. J Dent. 2017;67:36-42. http://dx.doi.org/10.1016/j. jdent.2017.07.013

13. Lee CT, Huang YW, Zhu L, Weltman R. Prevalences of periimplantitis and peri-implant mucositis: systematic review and meta-analysis. J Dent. 2017;62:1-12. http://dx.doi.org/10. 1016/j.jdent.2017.04.011

14. Rokn A, Aslroosta H, Akbari S, Najafi H, Zayeri F, Hashemi $\mathrm{K}$. Prevalence of peri-implantitis in patients not participating in well-designed supportive periodontal treatments: a crosssectional study. Clin Oral Implants Res. 2017;28(3):314-319. http://dx.doi.org/10.1111/clr.12800

15. Renvert S, Samuelsson E, Lindahl C, Persson GR. Mechanical non-surgical treatment of peri-implantitis: a double-blind randomized longitudinal clinical study. I: clinical results. J Clin Periodontol. 2009;36(7):604-609. http://dx.doi.org/10.1111/ j.1600-051X.2009.01421.x

16. Schwarz F, Bieling K, Latz T, Nuesry E, Becker J. Healing of intrabony peri-implantitis defects following application of a nanocrystalline hydroxyapatite (Ostim???) or a bovine-derived xenograft (Bio-Oss???) in combination with a collagen membrane (Bio-Gide???). A case series. J Clin Periodontol. 2006;33(7):491-499. http://dx.doi.org/10.1111/j.1600-051X. 2006.00936.x

17. Matarasso S, Iorio Siciliano $V$, Aglietta M, Andreuccetti G, Salvi GE. Clinical and radiographic outcomes of a combined resective and regenerative approach in the treatment of periimplantitis: A prospective case series. Clin Oral Implants Res. 2014;25(7):761-767. http://dx.doi.org/10.1111/clr.12183

18. Roccuzzo M, Gaudioso L, Lungo M, Dalmasso P. Surgical therapy of single peri-implantitis intrabony defects, by means of deproteinized bovine bone mineral with $10 \%$ collagen. J Clin Periodontol. 2016;43(3):311-318. http://dx.doi.org/10. 1111/jcpe.12516

19. Schwarz F, Sculean A, Bieling K, Ferrari D, Rothamel D, Becker J. Two-year clinical results following treatment of peri-implantitis lesions using a nanocrystalline hydroxyapatite 
or a natural bone mineral in combination with a collagen membrane. J Clin Periodontol. 2008;35(1):80-87. http:// dx.doi.org/10.1111/j.1600-051X.2007.01168.x

20. Schwarz F, Sahm N, Bieling K, Becker J. Surgical regenerative treatment of peri-implantitis lesions using a nanocrystalline hydroxyapatite or a natural bone mineral in combination with a collagen membrane: A four-year clinical follow-up report. J Clin Periodontol. 2009;36(9):807-814. http://dx.doi. org/10.1111/j.1600-051X.2009.01443.x

21. Nícoli LG, Pigossi SC, Marcantonio C, Leal Zandim-Barcelos D, Marcantonio E. Surgical treatment of implants affected by periimplantitis after 15 years of loading. Implant Dent. 2016;25(2):288-292. http://dx.doi.org/10.1097/ID.000000000 0000398

22. Daugela $P$, Cicciù $M$, Saulacic N. Surgical Regenerative Treatments for Peri-Implantitis: Meta-analysis of Recent Findings in a Systematic Literature Review. J Oral Maxillofac Res. 2016;7(3):e15. http://dx.doi.org/10.5037/jomr.2016.7315

23. lezzi G, Degidi M, Scarano A, Petrone G, Piattelli A. Anorganic Bone Matrix Retrieved 14 Years After a Sinus Augmentation Procedure: A Histologic and Histomorphometric Evaluation. J Periodontol. 2007;78(10):2057-61. http://dx.doi.org/10.19 02/jop.2007.070062

24. Mladenovic Z, Sahlin-Platt A, Andersson B, Johansson A, Bjorn $\mathrm{E}$, Ransjo $\mathrm{M}$. In vitro study of the biological interface of Bio-Oss: Implications of the experimental setup. Clin Oral Implants Res. 2013;24(3):329-35. http://dx.doi.org/10.1111/ j.1600-0501.2011.02334.x

25. Lee DZ, Chen ST, Darby IB. Maxillary sinus floor elevation and grafting with deproteinized bovine bone mineral: A clinical and histomorphometric study. Clin Oral Implants Res. 2012;23(8):918-24. http://dx.doi.org/10.1111/j.1600-0501. 2011.02239.x

26. Araújo MG, da Silva JCC, de Mendonça AF, Lindhe J. Ridge alterations following grafting of fresh extraction sockets in man: A randomized clinical trial. Clin Oral Implants Res. 2015;26(4):407-12. http://dx.doi.org/10.1111/clr. 12366

27. Mordenfeld A, Hallman M, Johansson CB, Albrektsson T. Histological and histomorphometrical analyses of biopsies harvested 11 years after maxillary sinus floor augmentation with deproteinized bovine and autogenous bone. Clin Oral Implants Res. 2010;21(9):961-970. http://dx.doi.org/10.1111/ j.1600-0501.2010.01939.x

28. Jovanovic SA. The management of peri-implant breakdown around functioning osseointegrated dental implants. J Periodontol. 1993;64(11 Suppl):1176-1183. http://dx.doi.org/10. 1902/jop.1993.64.11s.1176

29. Khoshkam V, Suárez-López Del Amo F, Monje A, Lin G, Chan H-L, Wang H-L. Long-term Radiographic and Clinical Outcomes of Regenerative Approach for Treating Periimplantitis: A Systematic Review and Meta-analysis. Int J Oral Maxillofac Implants. 2016;31(6):1303-1310. http://dx.doi. org/10.11607/jomi.4691

30. Lindhe J, Meyle J. Peri-implant diseases: Consensus Report of the Sixth European Workshop on Periodontology. J Clin Periodontol. 2008;35(8 Suppl):282-5. http://dx.doi.org/10.11 $11 / j .1600-051 X .2008 .01283 . x$
31. Heitz-Mayfield L, Mombelli A. The Therapy of Peri-implantitis: A Systematic Review. Int J Oral Maxillofac Implants. 2014;29(Supplement):325-45. http://dx.doi.org/10.11607/jomi. 2014suppl.g5.3

32. Schwarz F, Sahm N, Iglhaut G, Becker J. Impact of the method of surface debridement and decontamination on the clinical outcome following combined surgical therapy of peri-implantitis: A randomized controlled clinical study. J Clin Periodontol. 2011;38(3):276-84. http://dx.doi.org/10.1111/ j.1600-051X.2010.01690.x

33. Schwarz F, John G, Mainusch S, Sahm N, Becker J. Combined surgical therapy of peri-implantitis evaluating two methods of surface debridement and decontamination. A two-year clinical follow up report. J Clin Periodontol. 2012;39(8):789-97. http://dx.doi.org/10.1111/j.1600-051X.2012.01867.x

34. Moher D, Liberati A, Tetzlaff J AD. Preferred reporting items for systematic reviews and meta-analyses: the PRISMA statement. PLoS Med. 2009;6:1000097. http://dx.doi.org/10. 1371/journal.pmed1000097

35. Forrest J, Miller SA. Enhancing your practice through evidencebased decision making: Appraising the evidence. J Evid Based Dent Pract. 2002;2(2):178-85. http://dx.doi.org/10.1067/ med.2002.125538

36. Schwarz F, Hegewald A, John G, Sahm N, Becker J. Fouryear follow-up of combined surgical therapy of advanced peri-implantitis evaluating two methods of surface decontamination. J Clin Periodontol. 2013;40(10):962-7. http://dx.doi.org/10.1111/jcpe.12143

37. Schwarz F, Ferrari D, Popovski K, Hartig B, Becker J. Influence of different air-abrasive powders on cell viability at biologically contaminated titanium dental implants surfaces. J Biomed Mater Res - Part B Appl Biomater. 2009;88(1):83-91. http:// dx.doi.org/10.1002/jbm.b.31154

38. Schwarz F, Mihatovic I, Golubovic V, Eick S, Iglhaut T, Becker J. Experimental peri-implant mucositis at different implant surfaces. J Clin Periodontol. 2014;41(5):513-20. http://dx.doi. org/10.1111/jcpe. 12240

39. Roccuzzo M, Bonino F, Bonino L, Dalmasso P. Surgical therapy of peri-implantitis lesions by means of a bovine-derived xenograft: Comparative results of a prospective study on two different implant surfaces. J Clin Periodontol. 2011;38(8):738-45. http://dx.doi.org/10.1111/j.1600-051X.2011.01742.x

40. Hasuike A, Ueno D, Nagashima H, Kubota T, Tsukune N, Watanabe N, Sato S. Methodological quality and risk-of-bias assessments in systematic reviews oftreatments for periimplantitis. J Periodontal Res. 2019 Jan 22. [Epub ahead of print] http://dx.doi.org/10.1111/jre.12638

41 Hürzeler MB, Quiñones CR, Morrison EC, Caffesse RG. Treatment of peri-implantitis using guided bone regeneration and bone grafts, alone or in combination, in beagle dogs. Part 1: Clinical findings and histologic observations. Int J Oral Maxillofac Implants. 1997;10(4):474-84. http://dx.doi. org/10.1097/00008505-199605000-00042

42. Araújo MG, Lindhe J. Ridge preservation with the use of BioOss ${ }^{\circledR}$ collagen: A 6-month study in the dog. Clin Oral Implants Res. 2009;20(5):433-40. http://dx.doi.org/10.1111/j.1600-0501. 2009.01705.x 
43. Roccuzzo M, Gaudioso L, Bunino M, Dalmasso P. Long-Term Stability of Soft Tissues Following Alveolar Ridge Preservation: 10-Year Results of a Prospective Study Around Nonsubmerged Implants. Int J Periodontics Restor Dent. 2014;34(6):795-804. http://dx.doi.org/10.11607/prd.2133

44. Sahrmann P, Attin T, Schmidlin PR. Regenerative Treatment of Peri-Implantitis Using Bone Substitutes and Membrane: A Systematic Review. Clin Implant Dent Relat Res. 2011;13(1):4657. http://dx.doi.org/10.1111/j.1708-8208.2009.00183.x

45. Roos-Jans??ker AM, Lindahl C, Persson GR, Renvert S. Longterm stability of surgical bone regenerative procedures of peri-implantitis lesions in a prospective case-control study over 3 years. J Clin Periodontol. 2011;38(6):590-7. http:// dx.doi.org/10.1111/j.1600-051X.2011.01729.x

46. Roos-Jansåker AM, Persson G, Lindahl C, Renvert S. Surgical treatment of peri- implantitis using a bone substitute with or without a resorbable membrane: a 5-year follow-up. J Clin Periodontol. 2014;41:1108-14. http://dx.doi.org/10.1111/j.160 0-051X.2007.01102.x

47. Figuero E, Graziani F, Sanz I, Herrera D, Sanz M. Management of peri-implant mucositis and peri-implantitis. Periodontol 2000. 2014;66(1):255-73. http://dx.doi.org/10.1111/prd.12049

48. Chan H-L, Lin G-H, Suarez F, MacEachern M, Wang H-L. Surgical management of Peri-implantitis: a systematic review and meta-analysis of treatment outcomes. J Periodontol. 2014;85(8):1027-41. http://dx.doi.org/10.1902/ jop.2013.130563

49. Carcuac O, Derks J, Charalampakis G, Abrahamsson I, Wennström J, Berglundh T. Adjunctive Systemic and local antimicrobial therapy in the surgical treatment of periimplantitis: a randomized controlled clinical trial. J Dent Res. 2015;95(1):50-7. http://dx.doi.org/10.1177/002203451560 1961
50. Aghazadeh A, Rutger Persson G, Renvert S. A single-centre randomized controlled clinical trial on the adjunct treatment of intra-bony defects with autogenous bone or a xenograft: Results after 12 months. J Clin Periodontol. 2012;39(7):666-73. http://dx.doi.org/10.1111/j.1600-051X.2012.01880.x

51. Froum SJ, Froum SH, Rosen PS. Successful management of peri-implantitis with a regenerative approach: a consecutive series of 51 treated implants with 3- to 7.5-year follow-up. Int J Periodontics Restorative Dent. 2012;32(1):11-20.

52. Fu JH, Wang HL. Can Periimplantitis Be Treated? Dent Clin North Am. 2015;59(4):951-80. http://dx.doi.org/10.1016/j. cden.2015.06.004

53. John G, Becker J, Schwarz F. Modified implant surface with slower and less initial biofilm formation. Clin Implant Dent Relat Res. 2015;17(3):461-468. http://dx.doi.org/10.1111/cid. 12140

54. Papathanasiou E, Finkelman M, Hanley J, Parashis AO. Prevalence, Etiology and Treatment of Peri-implant Mucositis and Peri-implantitis: A Survey of us Periodontists. J Periodontol. 2016;87(5):493-501. http://dx.doi.org/ 10.1902/ jop.2015.150476

55. Dalago HR, Schuldt Filho G, Rodrigues MAP, Renvert S, Bianchini MA. Risk indicators for Peri-implantitis. A crosssectional study with 916 implants. Clin Oral Implants Res. 2017;28(2):144-50. http://dx.doi.org/10.1111/clr.12772

56. Berglundh T, Jepsen S, Stadlinger B, Terheyden H. Periimplantitis and its prevention. Clin Oral Implants Res. 2019;30(2):150-5. http://dx.doi.org/10.1111/clr.13401

Received on: 25/2/2019 Approved on: 28/2/2019 